\title{
Energy and exergy analysis of a novel turbo-compounding system for supercharging and mild hybridization of a gasoline engine
}

\author{
Farhad Salek $^{1} \cdot$ Meisam Babaie $^{2} \cdot$ Ali Ghodsi $^{1} \cdot$ Seyed Vahid Hosseini ${ }^{1} \cdot$ Ali $^{\text {Zare }}{ }^{3}$
}

Received: 27 May 2020 / Accepted: 7 August 2020 / Published online: 3 September 2020

(C) The Author(s) 2020

\begin{abstract}
Number of hybrid vehicles has increased around the world significantly. Automotive industry is utilizing the hybridization of the powertrain system to achieve better fuel economic and emissions reduction. One of the options recently considered in research for hybridization and downsizing of vehicles is to employ waste heat recovery systems. In this paper, the addition of a turbo-compound system with an air Brayton cycle (ABC) to a naturally aspirated engine was studied in AVL BOOST software. In addition, a supercharger was modeled to charge extra air into the engine and $\mathrm{ABC}$. The engine was first validated against the experimental data prior to turbo-compounding. The energy and exergy analysis was performed to understand the effects of the proposed design at engine rated speed. Results showed that between 16 and 18\% increase in engine mechanical power can be achieved by adding turbo-compressor. Furthermore, the recommended ABC system can recover up to $1.1 \mathrm{~kW}$ extra electrical power from the engine exhaust energy. The energy and exergy efficiencies were both improved slightly by turbo-compounding and BSFC reduced by nearly $1 \%$ with the proposed system. Furthermore, installing the proposed system resulted in increase in backpressure up to approximately $23.8 \mathrm{kPa}$.
\end{abstract}

Keywords Air Brayton cycle · Waste heat recovery · Hybridization · Supercharger · Turbo-compounding · Exergy · Downsizing

\section{List of symbols}

ABC Air Brayton cycle

a Vibe parameter

BDUR Burn duration (deg)

$\dot{\boldsymbol{E}} \quad$ Exergy rate $(\mathrm{kW})$

e Specific exergy $\left(\mathrm{kJ} \mathrm{kg}^{-1}\right)$

I Exergy destruction $(\mathrm{kW})$

$m \quad$ Vibe shape

$\dot{m} \quad$ Mass flow rate $\left(\mathrm{kg} \mathrm{s}^{-1}\right)$

ORC Organic Rankine cycle

$\dot{\boldsymbol{Q}} \quad$ Heat transfer rate $(\mathrm{kW})$

SOC Start of combustion (deg)

TC Turbo compressor

Meisam Babaie

m.babaie@salford.ac.uk

1 Faculty of Mechanical and Mechatronic Engineering, Shahrood University of Technology, Shahrood, Iran

2 School of Science, Engineering and Environment, University of Salford, Manchester, UK

3 Flow, Aerosols and Thermal Energy (FATE) Group, School of Engineering, Deakin University, Melbourne, VIC 3216, Australia

\begin{tabular}{ll} 
WHR & Waste heat recovery \\
$\dot{W}$ & Mechanical power $(\mathrm{kW})$ \\
$\propto$ & Crank shaft angle $(\mathrm{deg})$ \\
\multicolumn{2}{c}{ Subscripts } \\
C & Coolant \\
ch & Chemical \\
f & Fuel \\
HEX & Heat exchanger \\
ht & Heat transfer \\
ph & Physical
\end{tabular}

\section{Introduction}

Air pollution is one of the major challenges that many countries are envisaged today. Transportation sector among the sources of emissions is responsible for about $40 \% \mathrm{CO}_{2}$ emission around the world [1]. Apart from $\mathrm{CO}_{2}$, other harmful emissions such as particulate matters, $\mathrm{CO}, \mathrm{HC}$ and $\mathrm{NOx}$ are emitted from the vehicle tailpipes running by fossil fuels. Even in recent COVID-19 pandemic, a direct relationship between the number of death and air pollution was observed [2]. Governments around the word have started to respond to 
this threat through international commitment such as Paris agreement and emissions regulations [3], and Europe has set probably the most stringent standards targeting reduction of about $4 \% \mathrm{CO}_{2}$ yearly until 2030 [4].

Internal combustion (IC) engines burning fossil fuels were running the industries and transportations for many years. While it would be impossible to wipe off the IC engines completely in the near future, continuous improvements in fuel economy are required in automotive industry to achieve the vital targets set by standards [5-9]. To achieve this goal, researchers have been working on different solutions around the world such as using biofuel [10-15] and hydrogen energy $[16,17]$ as well as the hybridizations and electrifications [18-20] to reduce the engine fuel consumption and emissions. However, still further works are required to reduce the emissions from vehicles.

Approximately between 40 and $60 \%$ of fuel energy is wasted in IC engines through the exhaust [21, 22]. It is a huge share of energy especially considering the low efficiency of IC engines, and there is a great potential for recovering at least some of this wasted energy. Therefore, adding waste heat recovery (WHR) systems to IC engines could be viable in achieving a better fuel economy as it can result in increment of total engine power production and reduction of engine brake specific fuel consumption (BSFC) [21, 23, 24]. Moreover, extra electrical power will be generated by WHR systems which can be consumed directly or auxiliary in the vehicles.

There are many types of thermodynamic cycles which can be coupled to engines as the waste heat recovery system [25-29], and the most well-known one is the organic Rankine cycle (ORC) [21, 27]. This cycle contains four components in which the organic working fluid circulates in a cycle [22]. One of the most important thermophysical properties of organic fluids are their low heat of evaporation compared to other fluids, and they can be vaporized by absorbing heat from low-temperature heat sources [22]. Mahmoudi et al. [21] have reported that between 21 and $25 \%$ of engine exhaust waste heat can be recovered by the employment of recuperative single-loop and dual-loop ORCs, respectively. Salek et al. [22] have also studied the impact of ORC integrating for an internal combustion engine and showed that ORC was capable of recovering nearly $10 \%$ of wasted heat from the engine exhaust in a turbocharged diesel engine. Additionally, the CFD analysis of turbomachines used in ORC-WHR system was performed by different researchers to find the efficient solutions for increasing the thermal efficiency of the WHR [30].

Air Brayton cycle (ABC) is another cycle also recommended for WHR in the literature [24, 28, 29] which may have some advantages over ORC for vehicle engine applications as it is less complex. The lower number of ABC components when compared to ORC means that $\mathrm{ABC}$ will add less mass to vehicle than $\mathrm{ABC}$ in implementations. [31-33]. In addition, ORC needs its own working fluid, while the engine air can be used in $\mathrm{ABC}$ as the working fluid. Therefore, it seems using $\mathrm{ABC}$ in passenger cars is more beneficial than ORC.

The impacts of air Brayton cycle coupling to engine have been studied in the literature [34-37]. Nadera et al. [34] have investigated the fuel consumption reduction by employing $\mathrm{ABC}$ as the waste heat recovery system in a turbocharged gasoline fueled engine. In this study, part of the engine exhaust energy was absorbed by $\mathrm{ABC}$ heat exchanger for heating the $\mathrm{ABC}$ working fluid before entering the turbine. Based on the results of their work, vehicle fuel consumption decreased between 5.5 and $7 \%$ by using such waste heat recovery system. Song et al. [35] studied the performance of $\mathrm{ABC}$ coupled with a turbocharged diesel engine running at various engine speeds. An extra short fraction of the engine inlet air was also shared with Brayton cycle, and it is heated by the heat exchanger installed in engine exhaust system. The results showed that the engine fuel consumption decreased between 2.6 and $4.6 \%$ at different engine speeds. In another similar study [37], coupling ABC to a turbocharged diesel engine led to $\sim 0.64 \mathrm{~kW}$ power recovery at engine rated RPM.

Analysis of thermodynamic systems using exergy will provide a comprehensive insight into the system performance and losses. While energy "cannot be created or destroyed" (first law), exergy can be lost or destroyed during different process due to the irreversibilities (second law). Employing second law of thermodynamics (exergy analysis) will reveal the energy degradations process within the system that cannot be understood from the first law (energy) analysis [38]. The exergy analysis was employed in different energy systems including the engine research to highlight the engine improvements and losses by alternation in engine and/or fuel [16, 39-43]. When exergy analysis was employed in literature, it was mainly for commonly used ORC cycle for waste heat recovery of heavy-duty engines [40, 41, 43]. Valencia eta al. [40] investigated the impacts of coupling ORC on BSFC and exergy efficiency for a $2 \mathrm{MW}$ natural gas engine. Based on their results, BSFC decreased by nearly $7.67 \%$ at engine rated RPM. Salek et al. [43] have also studied a similar system in which a Kalina cycle was employed as the waste heat recovery system. It is reported that system exergy efficiency can be increased between 7.2 and $7.9 \%$ by integration of the waste heat recovery system. On the other hand, turbo-compounding systems have been widely used for small high RPM engines which are used in vehicle propulsion systems because of their low mass [44, 45]. A novel turbo-compounding system was introduced by $\mathrm{Zi}$ et al. [42] consisting of electric-booster and turbo-generator system. The engine waste heat was converted to electrical power by a turbine installed on engine exhaust system. The 
generated electrical power by turbine was used by electricbooster for supercharging the engine. As reported, the produced power by turbine can be managed in their system and exergy efficiency of vehicle propulsion system was increased by nearly $0.8 \%$.

As demonstrated, the focus of literature on using WHR system was on ORC and turbocharged engines with the high exhaust gas pressure. However, the benefits of installing the $\mathrm{ABC}$ on naturally aspirated gasoline fueled engine have not been studied. Furthermore, the exergy analysis can help in better understanding of the effectiveness of the WHR systems. Therefore, in this paper, the ABC was studied as the WHR system for hybridization and turbo-compounding of a naturally aspirated sport gasoline fueled engine. The exergy analysis was employed to explain the effect of adding turbocompounding system on the exergy performance parameters of the whole system. To develop this study, the experimental data were collected from the original engine to benchmark its performance. Then, the engine was modeled in AVL BOOST software, and the model was validated against the experimental data. Finally, the ABC was integrated into the engine to demonstrate the energy recovery from the waste heat through the exhaust. The recovered power was used to boost the air into the engine for producing more power, and the performance of engine has been evaluated at rated engine speed. A throttle was recommended for proposed $\mathrm{ABC}$ design to control the fraction of air entering the $\mathrm{ABC}$ heat exchanger. The exergy analysis has been performed to understand the effectiveness of adding $\mathrm{ABC}$ to the engine and finding the exergy destruction of the components.

\section{Methodology}

\section{Experimental set-up}

This study used a KIA Cerato engine, as demonstrated in the engine test room in Fig. 1. The technical specification of KIA Cerato engine is provided in Table 1.

To obtain the experimental data, the engine coupled with an eddy current dynamometer was tested and the engine
Table 1 Specifications of KIA Cerato engine

\begin{tabular}{lll}
\hline Parameter & Unit & Value \\
\hline Bore & $\mathrm{mm}$ & 86 \\
Stroke & $\mathrm{mm}$ & 86 \\
Connecting rod length & $\mathrm{mm}$ & 143.5 \\
Number of cylinders & & 4 \\
Displacement & $\mathrm{cc}$ & 2000 \\
Maximum power & $\mathrm{kW}$ & 92 \\
Maximum speed & $\mathrm{RPM}$ & 7000 \\
Rated speed & $\mathrm{RPM}$ & 6000 \\
Compression ratio & & 10.5 \\
\hline
\end{tabular}

torque and BSFC data were collected. The collected data were used to validate the AVL model, as described in next section.

The Schenck $190 \mathrm{~kW}$ dynamometer was used in engine test room for running the engine and collecting data at various conditions. In addition, the uncertainty of each measuring instrument is provided in Table 2.

\section{Engine mathematical model}

The AVL BOOST is a 1D thermodynamic simulation software for numerical modeling of internal combustion engines. In this paper, this software was used to model the tested engine. The model of our naturally aspirated Kia engine is shown in Fig. 2. As can be seen in Fig. 2, this model consists of four cylinders ( $\mathrm{C} 1, \mathrm{C} 2, \mathrm{C} 3$ and $\mathrm{C} 4$ blocks) with four fuel ports (I1, I2, I3 and I4 blocks). AC1 and CAT1 are the air cleaner and catalyst unit components in this figure.

\section{The combustion model}

The Vibe two zone combustion model was used for calculating the rate of heat release in mathematical model [47]. In this combustion model, the combustion chamber is divided into two zones: burnt and unburnt zones. Therefore, the temperatures of aforementioned zones are calculated separately and the fraction of unburned can be calculated precisely by
Fig. 1 The KIA Cerato engine on test bed
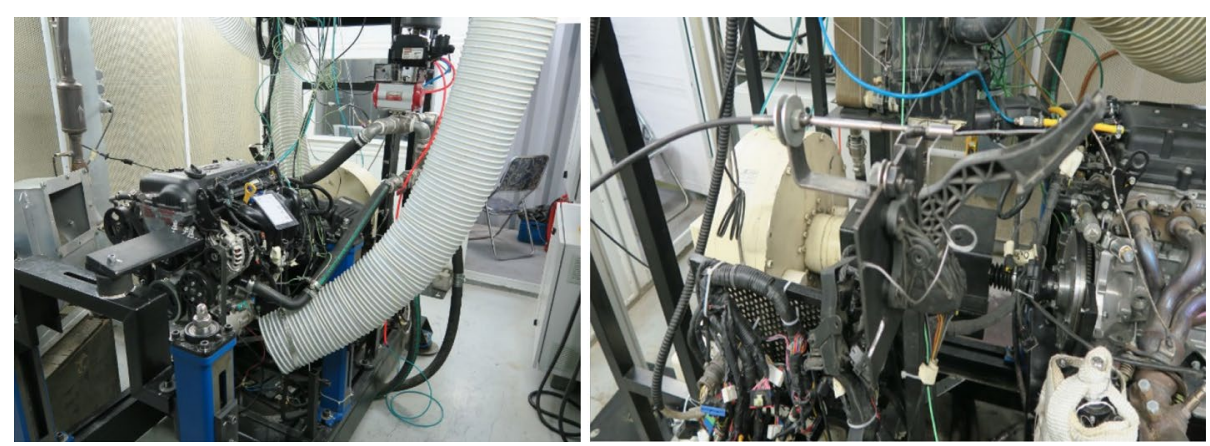
Table 2 Uncertainties of measuring instruments

\begin{tabular}{|c|c|c|c|c|c|}
\hline Parameter & Unit & Measuring equipment & Nominal value range & Uncertainty & $\begin{array}{l}\text { Relative uncer- } \\
\text { tainty/ } \%\end{array}$ \\
\hline Air temperature & ${ }^{\circ} \mathrm{C}$ & Dina engine connect [46] & $0-100$ & \pm 2 & 2 \\
\hline Air pressure & $\mathrm{kPa}$ & Dina engine connect [46] & $0-100$ & \pm 1 & 1 \\
\hline Relative Humidity & $\%$ & Dina engine connect [46] & $5-95$ & \pm 2.5 & 2.63 \\
\hline Fuel temperature & ${ }^{\circ} \mathrm{C}$ & Dina engine connect [46] & $0-100$ & \pm 0.2 & 0.2 \\
\hline Engine speed & RPM & Schenck $190 \mathrm{~kW}$ dynamometer [46] & $100-7000$ & \pm 4 & 0.06 \\
\hline Engine torque & $\mathrm{Nm}$ & Schenck 190 kW dynamometer [46] & $0-250$ & \pm 0.95 & 0.38 \\
\hline Engine power & $\mathrm{kW}$ & Schenck $190 \mathrm{~kW}$ dynamometer [46] & $0-190$ & \pm 1.2 & 0.63 \\
\hline Engine fuel consumption & $\mathrm{kg} \mathrm{h}^{-1}$ & Dina fuel mass flow meter [46] & $1-50$ & \pm 0.25 & 0.5 \\
\hline
\end{tabular}

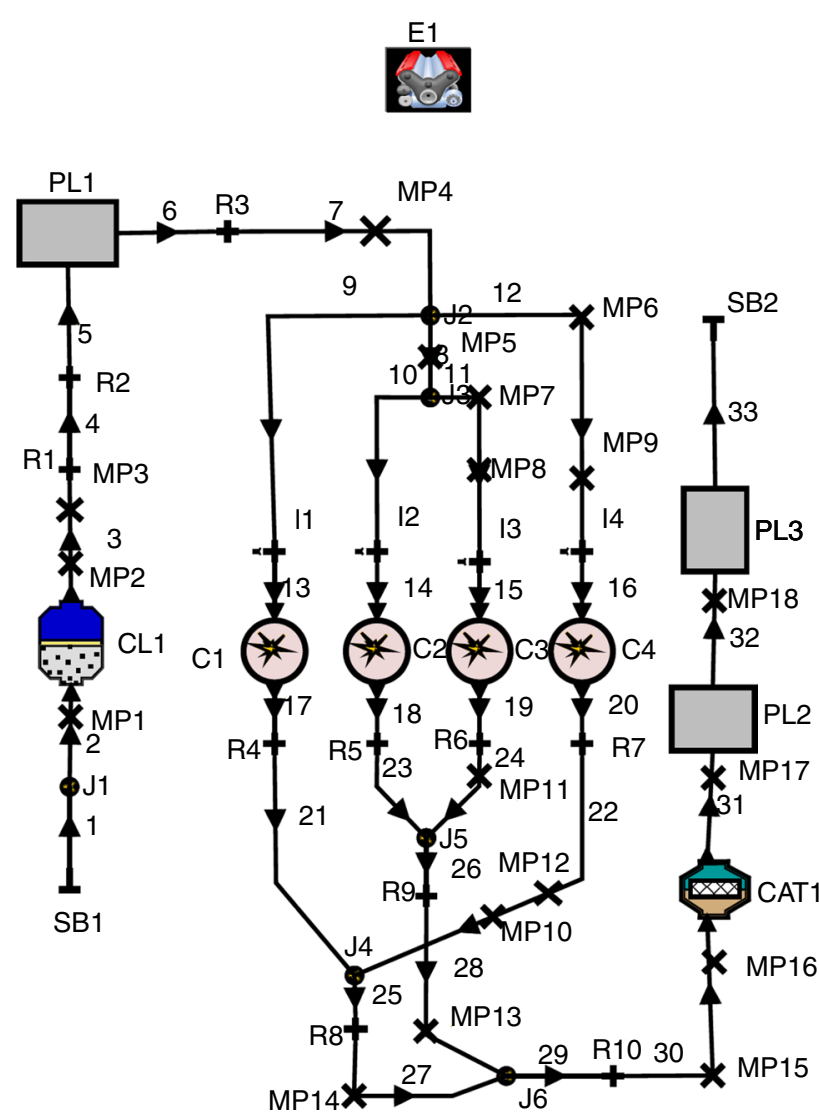

Fig. 2 Block diagram of engine model in AVL BOOST software

using such combustion model. Fuel mass burned fraction $(x)$ during combustion in Vibe two zone model is expressed as below:

$x=1-\exp \left[-a\left(\frac{\propto-\mathrm{SOC}}{\mathrm{BDUR}}\right)^{\mathrm{m}+1}\right]$

where SOC, BDUR, $\propto, m$ and a are the start of the combustion, burn duration, crankshaft angle, Vibe shape and
Vibe parameter, respectively. Vibe shape parameter indicates the position of the brunt for the combustion position. Also, Woschni model has been used for modeling of the heat transfer between gas and cylinder walls [48, 49].

\section{Air Brayton cycle}

The air Brayton cycle is a famous thermodynamic cycle consisting of four thermodynamic processes: compression of air in compressor (1 to 2), heating air in a heat exchanger ( 2 to 3 ), expansion of heated air in the turbine (3 to 4) and cooling the air at constant pressure (4-1) [50]. The $\mathrm{P}-\mathrm{V}$ and $\mathrm{T}-\mathrm{S}$ diagrams of $\mathrm{ABC}$ are shown in Fig. 3. Brayton cycle is the standard cycle of the gas turbine, and it is used widely in many industries as power production heat engines such as powerplants, airplanes and multi-generation systems [50].

In this study, the air Brayton cycle (ABC), shown in Fig. 4, was coupled to KIA Cerato engine for WHR. A turbo-compressor was added to engine for two purposes: charging extra air to engine (supercharging) and charging air to $\mathrm{ABC}$. The fraction of charged air entering $\mathrm{ABC}$ was controlled by a throttle [51-53] installed before $A B C$ heat exchanger. In fact, this throttle controls the rate of air shared between engine and $\mathrm{ABC}$. When it is closed, no air will enter the $\mathrm{ABC}$; therefore, all of the charged air will be transferred to engine to provide the maximum power. When the throttle is fully open, a small fraction of charged air is transferred to $\mathrm{ABC}$ and it is warmed up by absorbing heat energy from the engine exhaust in the heat exchanger. Then, it will be expanded in turbine to generate electrical power.

Figure 4 presents a schematic diagram of the proposed WHR system. As shown, the ABC recovered energy is proposed to produce extra electric power, while the engine is boost up by the turbo-compounding. The proposed system model is also shown in AVL BOOST software in Fig. 5. $\mathrm{TC} 1, \mathrm{~T} 1$ and $\mathrm{TH} 1$ are the turbo-compressor, turbine and throttle components. $\mathrm{CO} 1$ block is the heat exchanger where the engine exhaust flows and some of the wasted heat is 
Fig. $3 \mathrm{P}-\mathrm{V}$ and $\mathrm{T}-\mathrm{S}$ diagrams of a standard air Brayton cycle
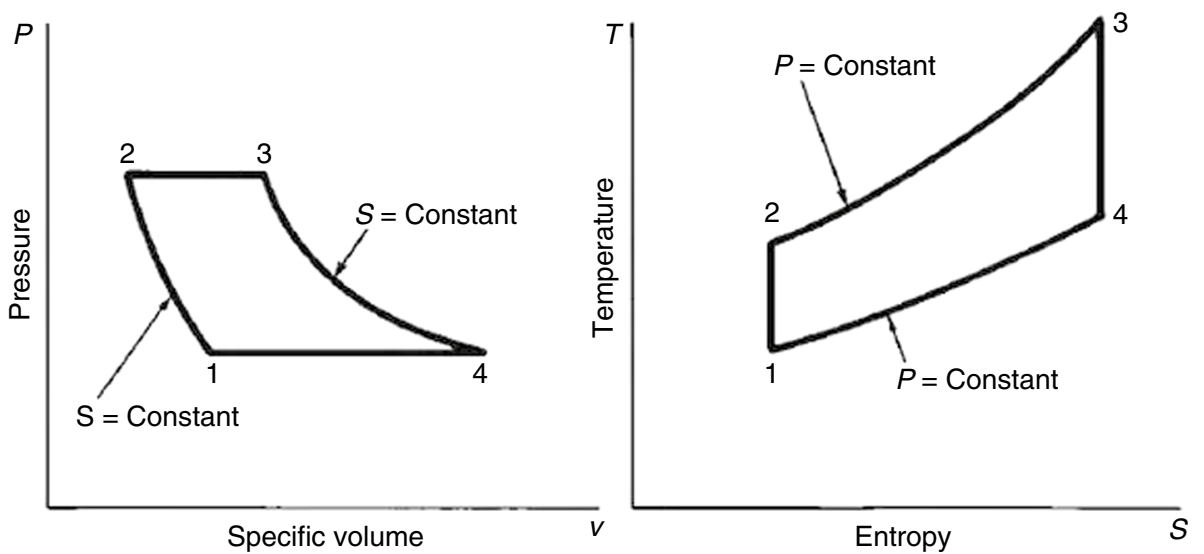

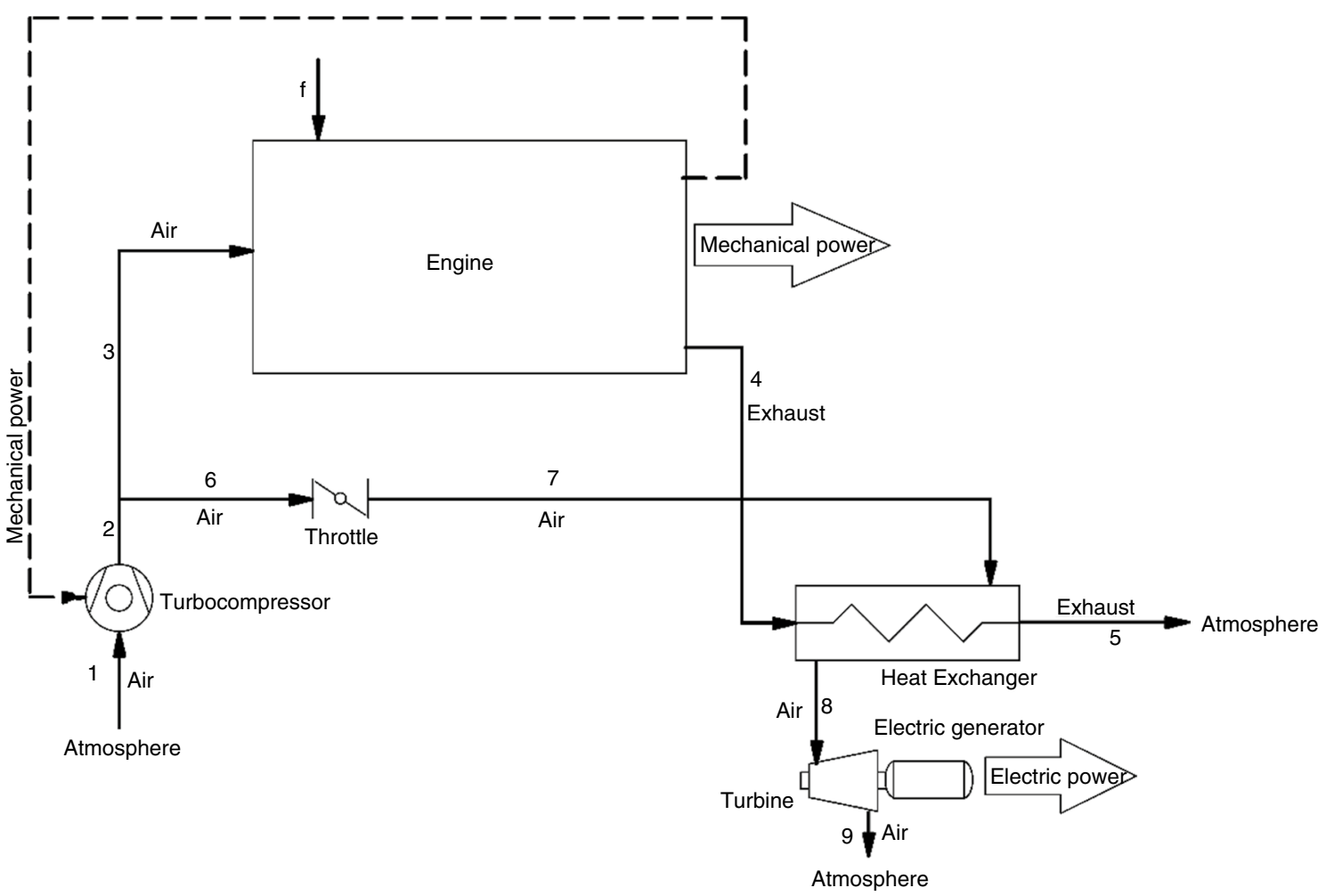

Fig. 4 Block diagram of turbo-compound system

transferred to cold flow via PL4 block. The specifications of the added turbo-compressor and turbine used in this model are shown in Table 3. In addition, ED1 component in AVL model is the electric generator which converts turbine mechanical power to electric power, and it is also shown in Fig. 4 as electric generator block.

\section{Exergy analysis}

The data required for exergy analysis were extracted from AVL software, and the engine thermodynamic model for exergy analysis was developed in MATLAB software. In exergy analysis, the air was assumed to be ideal gas in the model. In addition, the energy and exergy analysis of the system has been performed under the steady-state condition. The exergy balance concept was used to find the exergy destruction. The exergy destruction expressions for the main components of the system are presented in Table 4.

The exergy of fuel $\left(e_{\mathrm{f}}\right)$ and specific exergy of engine exhaust gas $\left(e_{4}\right)$ can be calculated from equations below $[16,27,39]$ : 


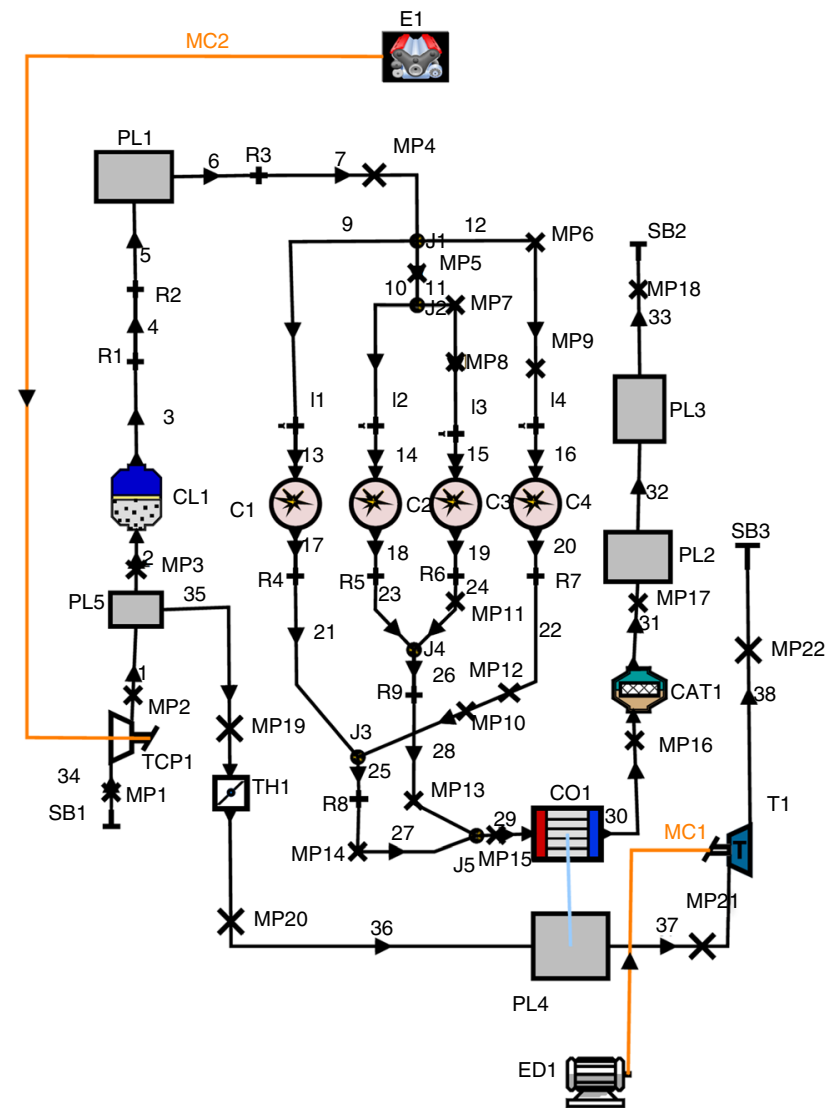

Fig. 5 Block diagram of turbo-compound system in AVL BOOST software

Table 3 The specifications of turbo-compressor (TC) and turbine

\begin{tabular}{ll}
\hline Parameter & Value \\
\hline TC pressure ratio & 1.2 \\
TC isentropic efficiency & 0.7 \\
TC mechanical efficiency & 0.9 \\
Turbine equivalent discharge coefficient & 0.045 \\
Turbine isentropic efficiency & 0.8 \\
Turbine mechanical efficiency & 0.98
\end{tabular}

Table 4 The exergy destruction expression for each component [16, 27, 39]

\begin{tabular}{ll}
\hline Components & Expressions \\
\hline Engine & $I_{\text {engine }}=\dot{m}_{3} e_{3}+\dot{m}_{f} e_{f}-\dot{m}_{4} e_{4}-\dot{E}_{\mathrm{ht}}-\dot{W}_{\text {engine }}$ \\
Turbo-compressor & $I_{\mathrm{TC}}=\dot{m}_{1} e_{1}-\dot{m}_{2} e_{2}+\dot{W}_{\mathrm{TC}}$ \\
Heat exchanger & $I_{\mathrm{HEX}}=\dot{m}_{4} e_{4}-\dot{m}_{5} e_{5}+\dot{m}_{7} e_{7}-\dot{m}_{8} e_{8}$ \\
Turbine & $I_{\text {Turbine }}=\dot{m}_{8} e_{8}-\dot{m}_{9} e_{9}-\dot{W}_{\text {Turbine }}$ \\
\hline
\end{tabular}

Table 5 The reference conditions for exergy analysis [39]

\begin{tabular}{lll}
\hline Parameter & Unit & Value \\
\hline Temperature $\left(\mathbf{T}_{0}\right)$ & $\mathrm{K}$ & 300 \\
Pressure $\left(\mathbf{P}_{0}\right)$ & bar & 1.01325 \\
\hline
\end{tabular}

Table 6 The mole fraction of each air component in the environment [39]

\begin{tabular}{ll}
\hline Components & Mole fraction/\% \\
\hline $\mathrm{O}_{2}$ & 20.35 \\
$\mathrm{H}_{2} \mathrm{O}$ & 3.03 \\
$\mathrm{~N}_{2}$ & 75.67 \\
$\mathrm{CO}$ & 0.007 \\
$\mathrm{CO}_{2}$ & 0.0345 \\
$\mathrm{H}_{2}$ & 0.00005 \\
Other & 0.90845 \\
\hline
\end{tabular}

$$
\begin{aligned}
e_{\mathrm{f}}= & \left(1.0401+0.1728 \frac{h}{c}+0.0432 \frac{o}{c}\right. \\
& \left.+0.2169 \frac{s}{c}\left(1-2.0628 \frac{h}{c}\right)\right) \mathrm{LHV}, \mathrm{kJ} \mathrm{kg}^{-1}
\end{aligned}
$$

$e_{4}=e_{\mathrm{ph} 4}+e_{\mathrm{ch} 4}, \mathrm{~kJ} \mathrm{~kg}^{-1}$,

where h, c, o, s, LHV, $e_{\mathrm{ph} 4}$ and $e_{\mathrm{ch} 4}$ are mass fractions of hydrogen, carbon, oxygen, sulfur contents, lower heating value of fuel, physical and chemical specific exergy of exhaust gas at stream 4, respectively. The expressions for calculation of physical and chemical exergies are:

$e_{\mathrm{ph} 4}=\left(h_{4}-h_{0}\right)-T_{0}\left(s_{4}-s_{0}\right), \mathrm{kJ} \mathrm{kg}^{-1}$

$\bar{e}_{\mathrm{ch} 4}=\bar{R} T_{0} \sum a_{\mathrm{i}} \ln \frac{x_{\mathrm{i}}}{x_{0}}, \mathrm{~kJ} \mathrm{kmol}^{-1}$,

where $x_{\mathrm{i}}, x_{0}, \bar{R}$ and $T_{0}$ are the mole fraction of $\mathrm{x}$ component, mole fraction of $\mathrm{x}$ component in the environment, international gas constant and temperature of reference condition, consecutively. The exergy rate of engine heat transfer to cooling jacket $\left(\dot{E}_{h t}\right)$ is calculated as follows:

$\dot{E}_{\mathrm{ht}}=\left(1-\frac{T_{0}}{T_{c}}\right) \dot{Q}_{\mathrm{c}}, \mathrm{kW}$,

where $T_{\mathrm{c}}$ and $\dot{Q}_{\mathrm{c}}$ are the average temperature of the engine coolant and the rate of heat transfer to it, respectively. The reference condition for exergy analysis and the mole fraction of the air components in the environment are provided in Tables 5 and 6 . The equations for calculation of system energy and exergy efficiencies are provided in Eqs. 7 and 8, respectively. 
$\eta_{\text {energy }}=\frac{\dot{W}_{\text {engine }}+\dot{W}_{\text {Turbine }}-\dot{W}_{\mathrm{TC}}}{\dot{m}_{\mathrm{f}} \mathrm{LHV}}$

$\eta_{\text {exergy }}=\frac{\dot{W}_{\text {engine }}+\dot{W}_{\text {Turbine }}-\dot{W}_{\mathrm{TC}}}{\dot{m}_{\mathrm{f}} e_{\mathrm{f}}}$

$\dot{W}_{\text {engine }}, \dot{W}_{\text {Turbine }}, \dot{W}_{\mathrm{TC}}$ and LHV are engine brake power, turbine output power, turbo-compressor and fuel lower heating value, consecutively.

\section{Validation}

The experimental data obtained by testing the engine in the test bed were compared to AVL model data for validation of AVL model. Based on the results of comparison which are shown in Fig. 6, the maximum error of AVL model is below $8 \%$ (less than $5 \%$ in most of the speeds).
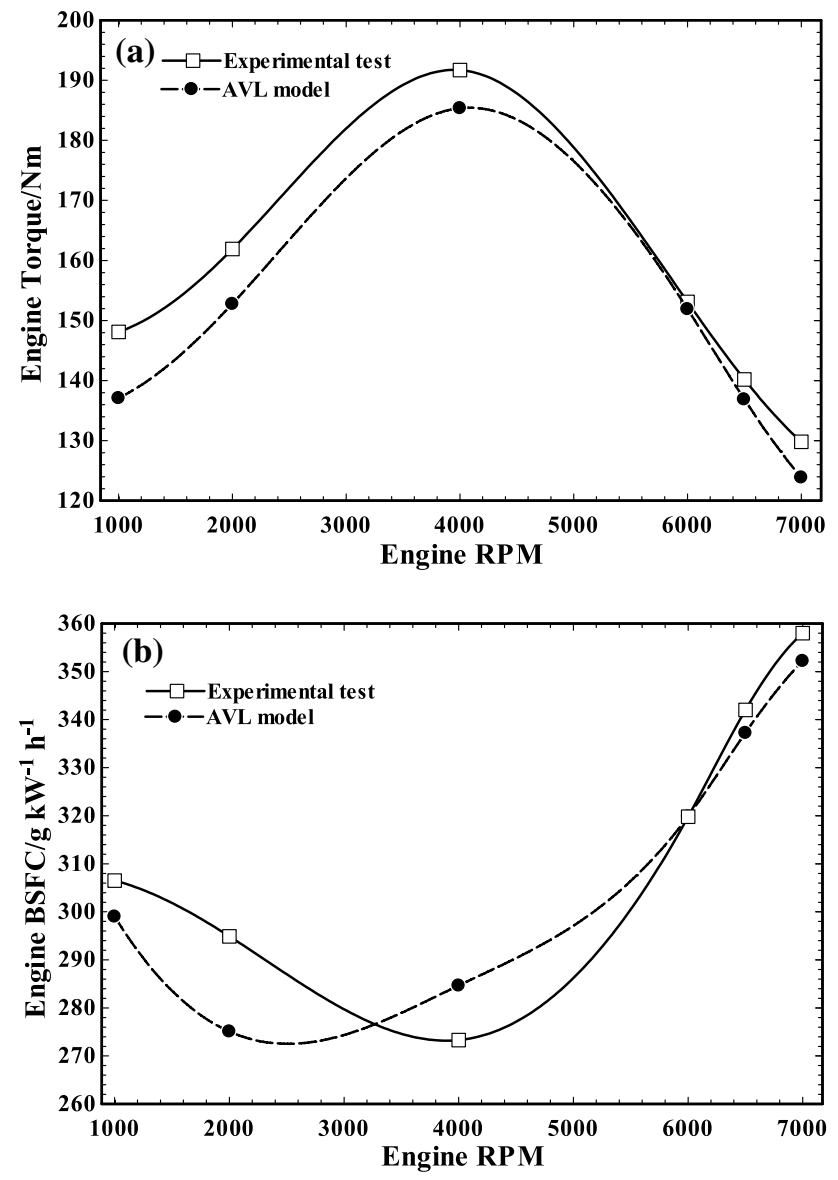

Fig. 6 Comparison of engine torque (a) and BSFC (b) in various RPMs of AVL model with experimental tests
Therefore, the model is valid and can represent the reality for further analysis.

\section{Result and discussion}

The effects of adding $\mathrm{ABC}$ as a turbo-compounding system in engine at different parameters were evaluated by solving the AVL model in AVL BOOST software at rated condition (6000 RPM). The thermophysical properties at different measure points were then extracted from AVL and exported to MATLAB software for exergy analysis.

Figure 7 shows the impacts of $\mathrm{ABC}$ throttle angles on engine and $\mathrm{ABC}$ air mass flow rates. The throttle was employed for controlling the mass flow rate of air between engine and $\mathrm{ABC}$ by providing a flexible system in which the amounts of electrical power generation of WHR system $(\mathrm{ABC})$ and extra mechanical power produced by engine can be controlled and adjusted in different conditions. When throttle angle was at 0 degree (i.e., it was closed), no air passed through the ABC system and it was on standby. The rate of air mass flow through engine decreases by increase in the throttle angle which leads to charging some of the turbocharged air into the $\mathrm{ABC}$ cycle (see Fig. 7).

The heat exchanger backpressure in various $\mathrm{ABC}$ throttle positions is shown in Fig. 8. The backpressure decreased from nearly 23.75 to $23.15 \mathrm{kPa}$ by increment of $\mathrm{ABC}$ throttle angle from 0 up to $90^{\circ}$. The engine power loss due to backpressure burden on engine is calculated by AVL BOOST and applied in final calculations.

The variation of engine and turbo-compressor power at different $\mathrm{ABC}$ throttle positions is shown in Fig. 9. The engine mechanical power is changed from $111.8 \mathrm{~kW}$ to nearly $110.5 \mathrm{~kW}$ by changing the $\mathrm{ABC}$ throttle position between $0^{\circ}$ and $90^{\circ}$. The engine power decreased minimally (1.16\%) by increment of throttle angle which led to charging

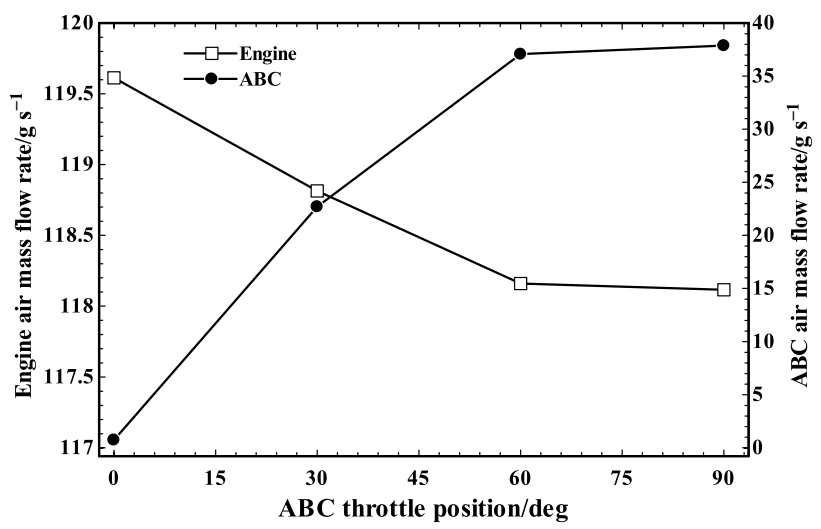

Fig. 7 Engine and $A B C$ air mass flow rates in various $A B C$ throttle positions 


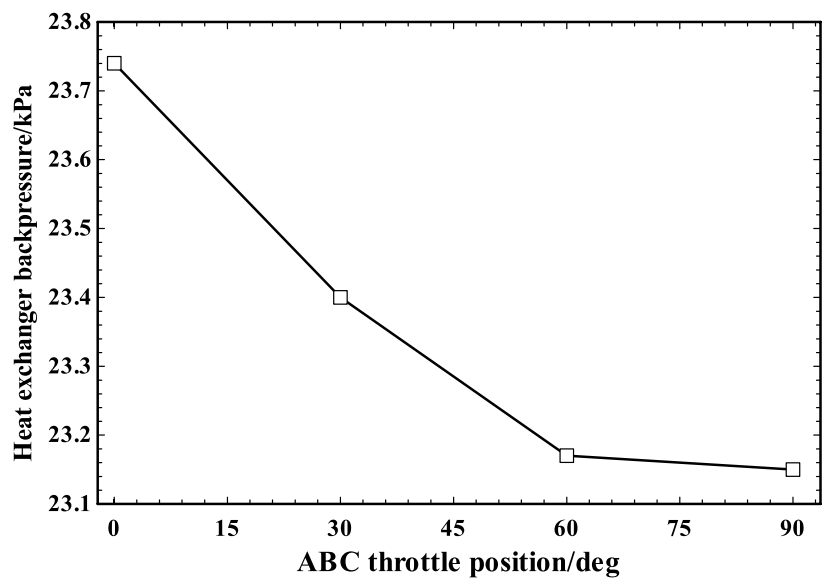

Fig. 8 The heat exchanger backpressure various $\mathrm{ABC}$ throttle angles

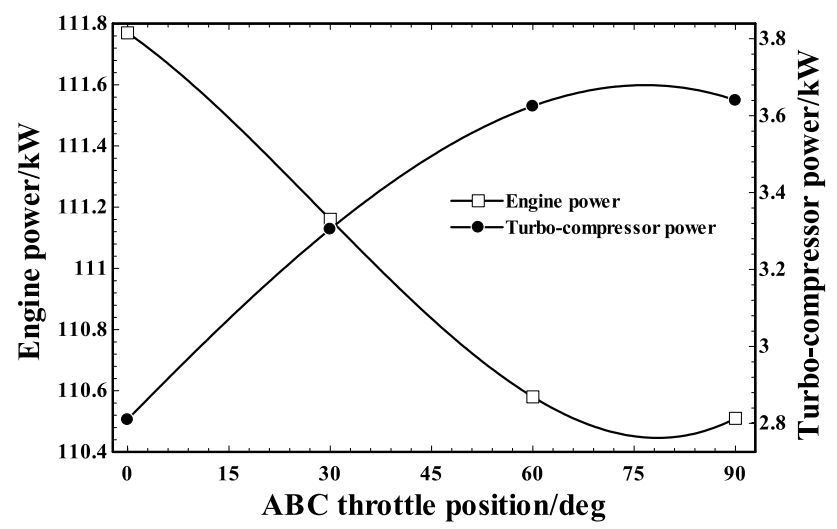

Fig. 9 Engine power output and turbo-compressor power consumption in various $\mathrm{ABC}$ throttle positions

less air into the engine and more air into the $\mathrm{ABC}$ cycle. Furthermore, the turbo-compressor power consumption increased by increase in the throttle angle. This is due to the increment of backpressure in whole system, as more power is needed for turbo-compressor to compensate the backpressure of the installed $\mathrm{ABC}$ components.

Figure 10 indicates the extra power available for the engine by installing the turbo-compressor which acts as a supercharging system at various $\mathrm{ABC}$ throttle angles. It should be noted that turbo-compressor power is provided mechanically from engine. The extra mechanical power of $17 \mathrm{~kW}$ was produced ( $18 \%$ increase in engine power) by adding turbo-compressor compared to the original naturally aspirated engine when the $\mathrm{ABC}$ throttle was completely closed. AF ratio is assumed to be constant; therefore, by increase of the air mass flow rate, the fuel mass flow rate increases which results in production of more power by the supercharged engine. Furthermore, as shown in this figure, the generated extra power decreased from 17 to $\sim 15.7 \mathrm{~kW}$ by changing the $\mathrm{ABC}$ throttle to fully open as the result

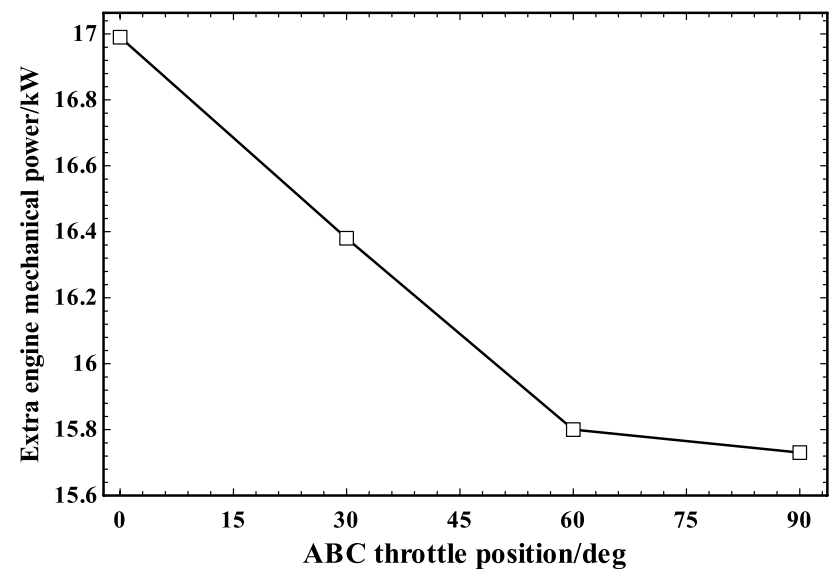

Fig. 10 Extra engine mechanical power output in various $\mathrm{ABC}$ throttle positions

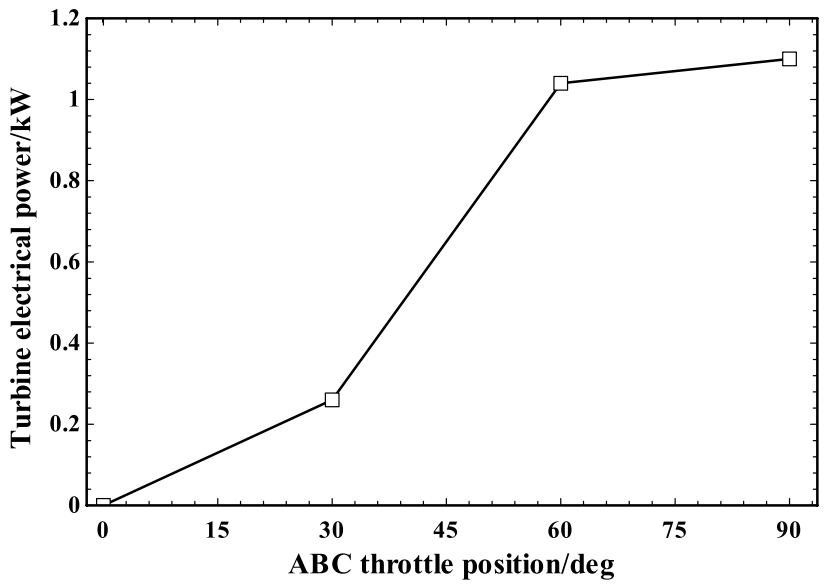

Fig. $11 \mathrm{ABC}$ turbine electrical power generation in various $\mathrm{ABC}$ throttle positions

of sharing of the compressed air between engine and $\mathrm{ABC}$ cycle.

The potential electrical power produced by $\mathrm{ABC}$ turbine at different $\mathrm{ABC}$ throttling positions is demonstrated in Fig. 11. There is a potential of recovering up to $1.1 \mathrm{~kW}$ from the exhaust at rated condition. The generated electrical power showed a rising trend by increase in the throttle angle due to the charging of more air into the $\mathrm{ABC}$ cycle for producing more electrical power.

Figure 12 shows the BSFC variation of supercharged and naturally aspirated engines as compared to $\mathrm{ABC}$ throttle angle. As it can be seen, the BSFC increases slightly by increase in the throttle angle to $30^{\circ}$ due to the reduction of engine power in supercharged engine. The minimal ABC power production will not overweight the engine power loss (due to the backpressure and lowering air mass flow rate) at this throttle position. On the other hand, the BSFC 


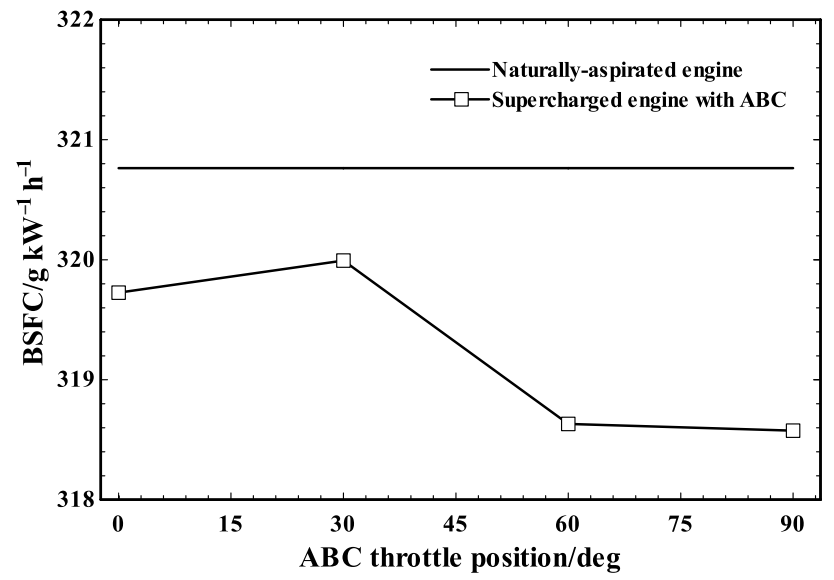

Fig. 12 BSFC of naturally aspirated and supercharged engine at various $\mathrm{ABC}$ throttle positions

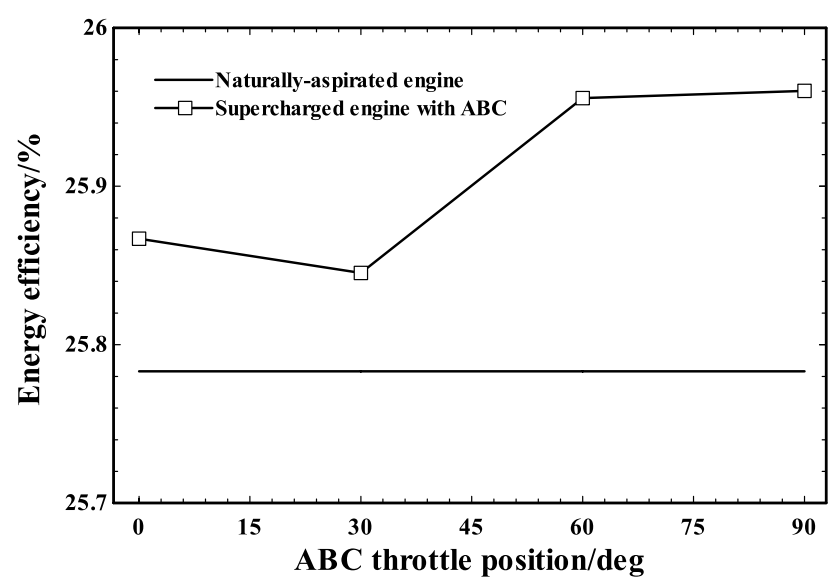

Fig. 13 Energy efficiencies of naturally aspirated and supercharged engine at various $\mathrm{ABC}$ throttle positions

decreased to nearly $318.5 \mathrm{~g} \mathrm{kWh}^{-1}$ when the throttle angle increased from 30 to $60^{\circ}$. The minimum of BSFC was happening at $\mathrm{ABC}$ throttle between 60 and $90^{\circ}$ as demonstrated in Fig. 12. By comparing the naturally aspirated engine and supercharged engine (with $\mathrm{ABC}$ ), it was found that engine BSFC was slightly improved $(\sim 1 \%)$ by adding the turbocompound system.

Figures 13 and 14 indicate the exergy and energy efficiencies trends of naturally aspirated engine and supercharged engine (with $\mathrm{ABC}$ ) by changing $\mathrm{ABC}$ throttling position. As shown, employment of turbo-compound system improved both the exergy and energy efficiencies slightly (nearly 1\%) in supercharged engine compared to original naturally aspirated engine. Since employing supercharger and injecting more air corresponds to burning more fuel at constant air/ fuel (AF) ratio, as expected, the exergy and energy efficiencies have not been changed considerably. Furthermore, by

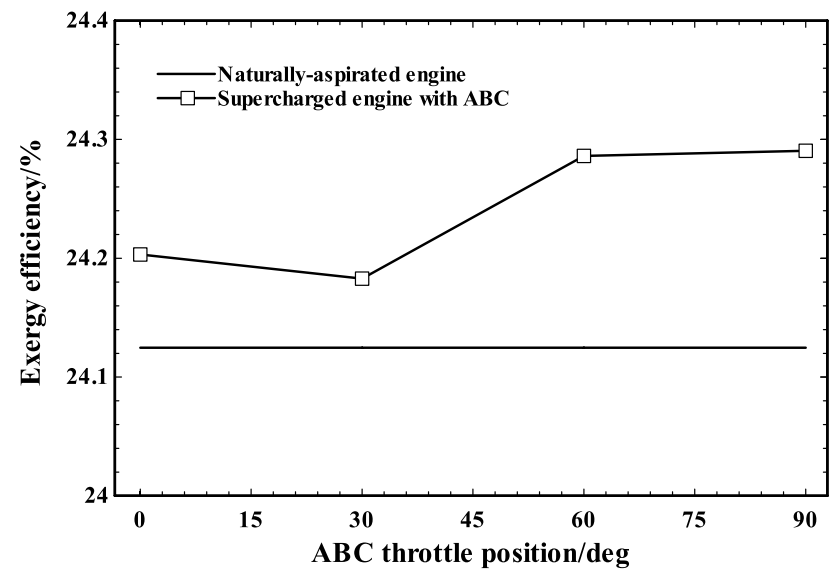

Fig. 14 Exergy efficiencies of naturally aspirated and supercharged engine at various $\mathrm{ABC}$ throttle positions

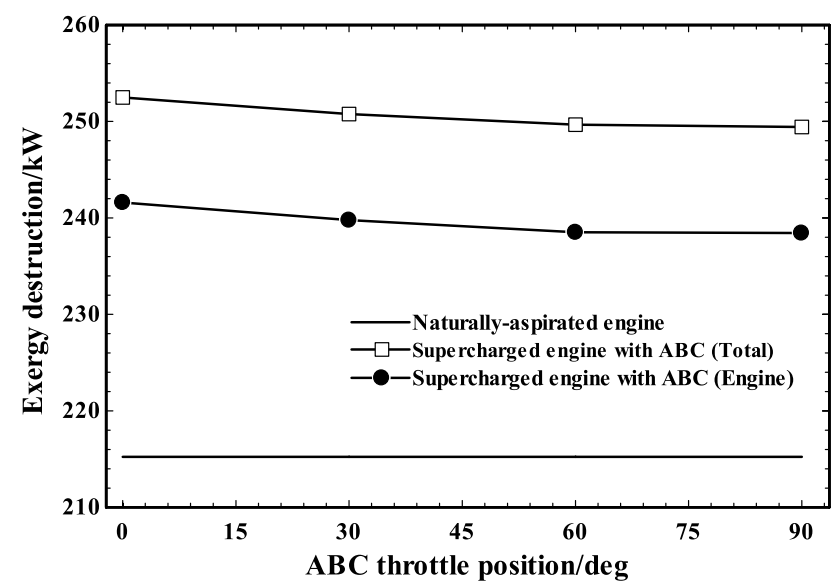

Fig. 15 The Exergy destruction of whole system and engine in various ABC throttle angles

increase in $\mathrm{ABC}$ throttle angle, both exergy and energy efficiencies of system are increased. Therefore, activation of $\mathrm{ABC}$ system resulted in increase in supercharged engine energy and exergy efficiencies. It can be inferred from Fig. 14 that the amount of exergy improvement of turbocompounding system is similar to previous study of turbocompounding system conducted by Zi et al. [42].

The exergy destruction is another important parameter demonstrating how efficient a component is operating and if there is a room for improvement. The exergy destruction of the total system including engine, turbo-compressor and $\mathrm{ABC}$ components as well as the engine block itself is presented in Fig. 15 and compared to original exergy destruction of the naturally aspirated engine. As shown, both engine and total exergy destruction were decreasing by $\mathrm{ABC}$ throttle position. In general, by adding more components, we should expect more total exergy destruction when comparing the 


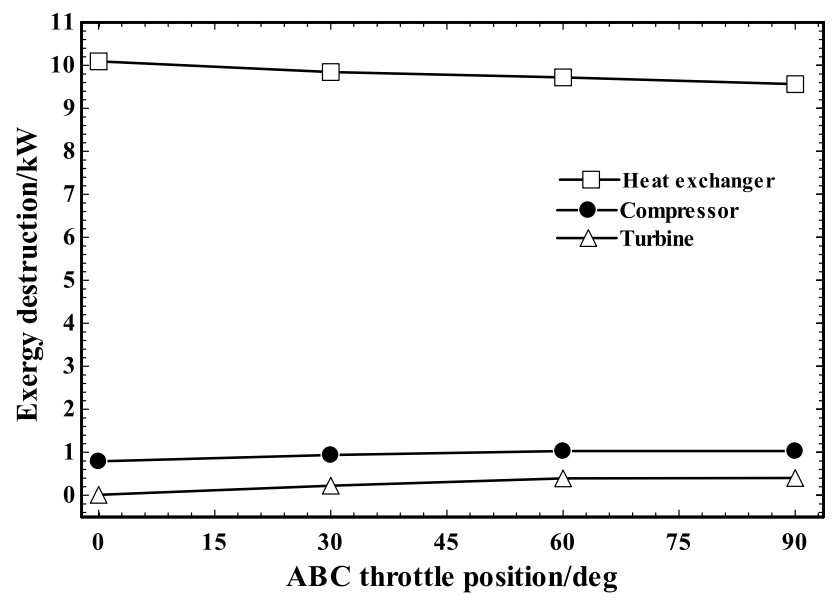

Fig. 16 The exergy destruction of heat exchanger, compressor and turbine in various $\mathrm{ABC}$ throttle angles

original and modified engines. Comparing the engine block for naturally aspirated engine and supercharged engine, the exergy destructions of supercharged engine were moderately higher. It happened because extra air was transferred into the engine by supercharger resulted in injection of more fuel (at constant AF ratio) which led to increment of the exergy destruction.

Figure 16 demonstrates the exergy destruction for each of the $\mathrm{ABC}$ components at various throttle positions. The exergy destruction of the heat exchanger decreased slightly by the increase in $\mathrm{ABC}$ throttle angles due to the reduction in engine power production. However, a small increase in turbo-compressor and turbine exergy destructions was observed by increase in the ABC throttle angle which is resulted from increase in $\mathrm{ABC}$ charging air and power generation.

\section{Conclusions}

In this paper, the energy and exergy analysis of installing a novel turbo-compound system for supercharging and mild hybridization of a naturally aspirated engine was performed using a KIA Cerato engine which was modeled numerically in AVL BOOST software. The results of modeling were compared to experimental data for validation. Additionally, the exergy model of whole system was developed to better understand the engine performance. The $\mathrm{ABC}$ was used in this study because it has less components and complexity compared to widely used ORC system; therefore, it imposes lower additional mass and pressure drop on vehicle. The results have shown a slight increase in BSFC, energy and exergy efficiencies of supercharged engine compared to naturally aspirated engine by employment of $A B C$ as waste heat recovery system. Furthermore, employment of $\mathrm{ABC}$ led to production of up to $1.1 \mathrm{~kW}$ extra power which can be used for parasitic loads or powering a battery in mild hybridization. The main conclusion drawn from this paper can be listed as:

- Adding turbo-compressor increased the engine power output approximately between 16 and $18 \%$.

- The turbo-compressor power consumption increased by increment of $\mathrm{ABC}$ throttle angle

- The engine power output can be controlled by ABC throttle position and it reduced by about $1.3 \mathrm{~kW}$ when $\mathrm{ABC}$ throttle gets fully open.

- The ABC turbine was capable of producing up to $\sim 1.1 \mathrm{~kW}$ electrical power at the engine rated speed.

- Adding turbo-compound system to engine resulted in small reduction in BSFC of about $1 \%$.

- The system energy and exergy efficiencies increased slightly by adding turbo-compound system. This can be optimized by adjusting the AF ratio in future research.

- The average exergy destruction of engine, heat exchanger, turbo-compressor and turbine were 239, 9.9, 0.95 and $0.2 \mathrm{~kW}$, respectively.

- The backpressure caused by installing the heat exchanger on engine exhaust system was between 23.1 and $23.8 \mathrm{kPa}$, at different throttle positions.

Acknowledgements AVL List GmbH support for proving the simulation tools for University of Salford through their University Partnership Program is greatly appreciated. Special thanks to Dina Motors company for their support during this research.

Open Access This article is licensed under a Creative Commons Attribution 4.0 International License, which permits use, sharing, adaptation, distribution and reproduction in any medium or format, as long as you give appropriate credit to the original author(s) and the source, provide a link to the Creative Commons licence, and indicate if changes were made. The images or other third party material in this article are included in the article's Creative Commons licence, unless indicated otherwise in a credit line to the material. If material is not included in the article's Creative Commons licence and your intended use is not permitted by statutory regulation or exceeds the permitted use, you will need to obtain permission directly from the copyright holder. To view a copy of this licence, visit http://creativecommons.org/licenses/by/4.0/.

\section{References}

1. Andreoni V, Galmarini S. European $\mathrm{CO} 2$ emission trends: a decomposition analysis for water and aviation transport sectors. Energy. 2012;45(1):595-602.

2. Wu X, Nethery RC, Sabath BM, Braun D, Dominici F. Exposure to air pollution and COVID-19 mortality in the United States. medRxiv. 2020.

3. Haszeldine RS, Flude S, Johnson G, Scott V. Negative emissions technologies and carbon capture and storage to achieve the Paris 
Agreement commitments. Philos Trans R Soc A Math Phys Eng Sci. 2018;376(2119):20160447.

4. Pasaoglu G, Honselaar M, Thiel C. Potential vehicle fleet $\mathrm{CO} 2$ reductions and cost implications for various vehicle technology deployment scenarios in Europe. Energy Policy. 2012;40:404-21.

5. Rajak U, Nashine P, Verma TN. Effect of spirulina microalgae biodiesel enriched with diesel fuel on performance and emission characteristics of CI engine. Fuel. 2020;268:117305.

6. Rajak U, Nashine P, Verma TN, Pugazhendhi A. Performance and emission analysis of a diesel engine using hydrogen enriched n-butanol, diethyl ester and Spirulina microalgae biodiesel. Fuel. 2020;271:117645.

7. Shrivastava P, Verma TN, Samuel OD, Pugazhendhi A. An experimental investigation on engine characteristics, cost and energy analysis of CI engine fuelled with Roselle, Karanja biodiesel and its blends. Fuel. 2020;275:117891.

8. Verma P, Dwivedi G, Behura AK, Patel DK, Verma TN, Pugazhendhi A. Experimental investigation of diesel engine fuelled with different alkyl esters of Karanja oil. Fuel. 2020;275:117920.

9. Panchal B, Chang T, Qin S, Sun Y, Wang J, Bian K. Corrigendum to "Process optimization using novel acidic ionic liquids and the kinetics modeling of methyl esters using Jatropha curcas oil with dimethyl carbonate"[Fuel 258 (2019) 116165]. Fuel. 2020;279:118476.

10. Balasubramanian K, Purushothaman K. Effect of acetylene addition on performance, emission and combustion characteristics of neem biodiesel and corn biodiesel-fueled $\mathrm{CI}$ engine. J Therm Anal Calorim. 2019;138(2):1405-14.

11. de Oliveira TF, Dweck J. Liquid phase oxidation quantitative analysis of biodiesel/diesel blends by differential TG and DTA. J Therm Anal Calorim. 2018;134(3):1953-63.

12. Elumalai $P$, Annamalai K, Dhinesh B. Effects of thermal barrier coating on the performance, combustion and emission of DI diesel engine powered by biofuel oil-water emulsion. J Therm Anal Calorim. 2019;137(2):593-605.

13. Rodríguez RP, Sierens R, Verhelst $S$. Thermal and kinetic evaluation of biodiesel derived from soybean oil and higuereta oil. J Therm Anal Calorim. 2009;96(3):897-901.

14. Krishania N, Rajak U, Verma TN, Birru AK, Pugazhendhi A. Effect of microalgae, tyre pyrolysis oil and Jatropha biodiesel enriched with diesel fuel on performance and emission characteristics of CI engine. Fuel. 2020;278:118252.

15. Krishania N, Rajak U, Chaurasiya PK, Singh TS, Birru AK, Verma TN. Investigations of spirulina, waste cooking and animal fats blended biodiesel fuel on auto-ignition diesel engine performance, emission characteristics. Fuel. 2020;276:118123.

16. Namar MM, Jahanian O. Energy and exergy analysis of a hydrogen-fueled HCCI engine. J Therm Anal Calorim. 2019;137(1):205-15.

17. Qin Z, Yang Z, Jia C, Duan J, Wang L. Experimental study on combustion characteristics of diesel-hydrogen dual-fuel engine. Journal of Thermal Analysis and Calorimetry. 2020:1-9.

18. Ekström FB, Rolandson O, Eriksson S, Odenmarck C, Svensson M, Eriksson A et al. A mild hybrid SIDI turbo passenger car engine with organic rankine cycle waste heat recovery: SAE technical paper 2019. Report No.: 0148-7191.

19. Ahmed R, Galal IAA, EL-Sharkawy M. Waste heat recovery for hybrid electric vehicles using thermoelectric generation system. J Adv Eng Trends. 2020;38(2):173-84.

20. Hannan M, Hoque M, Mohamed A, Ayob A. Review of energy storage systems for electric vehicle applications: issues and challenges. Renew Sustain Energy Rev. 2017;69:771-89.

21. Mahmoudi A, Fazli M, Morad M. A recent review of waste heat recovery by organic Rankine cycle. Appl Therm Eng. 2018;143:660-75.
22. Salek F, Moghaddam AN, Naserian MM. Thermodynamic analysis of diesel engine coupled with ORC and absorption refrigeration cycle. Energy Convers Manag. 2017;140:240-6.

23. Shi L, Shu G, Tian H, Deng S. A review of modified organic Rankine cycles (ORCs) for internal combustion engine waste heat recovery (ICE-WHR). Renew Sustain Energy Rev. 2018:92:95-110.

24. Nader WB, Mansour C, Dumand C, Nemer M. Brayton cycles as waste heat recovery systems on series hybrid electric vehicles. Energy Convers Manag. 2018;168:200-14.

25. Sheshpoli MA, Ajarostaghi SSM, Delavar MA. Thermodynamic analysis of waste heat recovery from hybrid system of proton exchange membrane fuel cell and vapor compression refrigeration cycle by recuperative organic Rankine cycle. J Therm Anal Calorim. 2019;135(3):1699-712.

26. Nouri M, Namar MM, Jahanian O. Analysis of a developed Brayton cycled CHP system using ORC and CAES based on first and second law of thermodynamics. J Therm Anal Calorim. 2019;135(3):1743-52.

27. Ahmadi B, Golneshan AA, Arasteh H, Karimipour A, Bach Q-V. Energy and exergy analysis and optimization of a gas turbine cycle coupled by a bottoming organic Rankine cycle. J Thermal Anal Calorim. 2019;141:1-16.

28. Cheng K, Qin J, Sun H, Dang C, Zhang S, Liu X, et al. Performance assessment of a closed-recuperative-Brayton-cycle based integrated system for power generation and engine cooling of hypersonic vehicle. Aerosp Sci Technol. 2019;87:278-88.

29. Di Battista D, Carapellucci R, Cipollone R. Integrated evaluation of Inverted Brayton cycle recovery unit bottomed to a turbocharged diesel engine. Appl Thermal Eng. 2020;175:115353.

30. Pinto RN, Afzal A, D'Souza LV, Ansari Z, Samee AM. Computational fluid dynamics in turbomachinery: a review of state of the art. Arch Comput Methods Eng. 2017;24(3):467-79.

31. Daabo AM, Mahmoud S, Al-Dadah RK (eds). Structural analysis of small scale radial turbine for solar powered Brayton cycle Application. In: ASME 2018 12th international conference on energy sustainability collocated with the ASME 2018 power conference and the ASME 2018 nuclear forum; 2018: American Society of Mechanical Engineers Digital Collection.

32. Shu G, Shi L, Tian H, Chang L. Comparison and selection research of $\mathrm{CO} 2$-based transcritical rankine cycle using for gasoline and diesel engine's waste heat recovery. Heat Transf Eng. 2018;39(7-8):672-86.

33. Shi L, Shu G, Tian H, Wang X. Assessment of waste heat recovery system for automotive engine with weight effect. Energy. 2020;193:116663.

34. Nadera WB, Mansourb C, Dumandc C, Nemerd M. Potential of fuel consumption saving of Brayton waste heat recovery systems on series hybrid electric vehicles. Proceeding of ECOS 2018 - The 31st internatioanl conference on efficiebcy, cost, optimisation, simulation and environental impact of energy systems, Portugal, 2018.

35. Song B, Zhuge W, Zhao R, Zheng X, Zhang Y, Yin Y, et al. An investigation on the performance of a Brayton cycle waste heat recovery system for turbocharged diesel engines. J Mech Sci Technol. 2013;27(6):1721-9.

36. Khalifa $\mathrm{H}$. Waste heat recovery from adiabatic diesel engines by exhaust-driven Brayton cycles. United Technologies Research Center. 1983;DOE/NASA/0304-1

37. Teo A, Chiong M, Yang M, Romagnoli A, Martinez-Botas R, Rajoo S. Performance evaluation of low-pressure turbine, turbocompounding and air-Brayton cycle as engine waste heat recovery method. Energy. 2019;166:895-907.

38. Esen H, Inalli M, Esen M, Pihtili K. Energy and exergy analysis of a ground-coupled heat pump system with two horizontal ground heat exchangers. Build Environ. 2007;42(10):3606-15. 
39. Odibi C, Babaie M, Zare A, Nabi MN, Bodisco TA, Brown RJ. Exergy analysis of a diesel engine with waste cooking biodiesel and triacetin. Energy Convers Manag. 2019;198:111912.

40. Valencia G, Fontalvo A, Cárdenas Y, Duarte J, Isaza C. Energy and exergy analysis of different exhaust waste heat recovery systems for natural gas engine based on ORC. Energies. 2019;12(12):2378.

41. Liao G, Jiaqiang E, Zhang F, Chen J, Leng E. Advanced exergy analysis for organic Rankine cycle-based layout to recover waste heat of flue gas. Appl Energy. 2020;266:114891.

42. Zi D, Zhang L, Chen B, Zhang Q. Study of the electric-booster and turbo-generator system and its influence on a $15 \mathrm{~L}$ gasoline engine. Appl Thermal Eng. 2019;162:114236.

43. Salek F, Eskandary Nasrabad A, Naserian M. Turbocharged diesel engine power production enhancement: proposing a novel thermal-driven supercharging system based on Kalina cycle. Renew Energy Res Appl. 2020;1(2):223-34.

44. Aghaali H, Angström H-E. A review of turbocompounding as a waste heat recovery system for internal combustion engines. Renew Sustain Energy Rev. 2015;49:813-24.

45. He G, Xie H. Fuel saving potential of different turbo-compounding systems under steady and driving cycles: SAE Technical Paper 2015. Report No.: 0148-7191.

46. Dinamotors Company. www.dinamotors.com.

47. Magryta P, Wendeker M, Majczak A, Bialy M, Siadkowska K. simulation studies of SI engine that meets the Euro5 standard, supply by gasoline with the hydrogen addition: SAE technical paper 2014. Report No.: 0148-7191.
48. Ogink R, Golovitchev V. Gasoline HCCI modeling: Computer program combining detailed chemistry and gas exchange processes. SAE Transactions. 2001:2338-50.

49. Kitanoski F, Puntigam W, Kozek M, Hager J. An engine heat transfer model for comprehensive thermal simulations: SAE technical paper 2006. Report No.: 0148-7191.

50. Cengel YA, Boles MA. Thermodynamics: an engineering approach. 8th ed. New York: McGraw-Hill Education; 2015. p. $502-5$.

51. Satou S, Nakagawa S, Kakuya H, Minowa T, Nemoto M, Konno $\mathrm{H}$. An accurate torque-based engine control by learning correlation between torque and throttle position: SAE technical paper 2008. Report No.: 0148-7191.

52. Stefanopoulou A, Grizzle J, Freudenberg J, editors. Engine air-fuel ratio and torque control using secondary throttles. In Proceedings of 1994 33rd IEEE conference on decision and control; 1994: IEEE.

53. Fekete N, Nester U, Gruden I, Powell J. Model-based air-fuel ratio control of a lean multi-cylinder engine. SAE transactions. 1995:1455-67.

Publisher's Note Springer Nature remains neutral with regard to jurisdictional claims in published maps and institutional affiliations. 